\title{
Regulation of Foreign Workers Based on Job Creation Act of Maslahah Perspective
}

\author{
Siti Nur Fitriana ${ }^{1}$, Iffatin Nur ${ }^{2}$ \\ 1UIN Sayyid Ali Rahmatullah Tulungagung \\ e-mail:sitinurfitriana15@gmail.com \\ 2UIN Sayyid Ali Rahmatullah Tulungagung \\ e-mail:iffaeltinury@gmail.com
}

\begin{tabular}{|l|l|l|}
\hline Received: 09-07-2021 & Revised: 28-10-2021 & Accepted: 10-11-2021 \\
\hline
\end{tabular}

\begin{abstract}
The Omnibus Law Bill which has been passed into law number 11 of 2020 concerning Work Creation has generated a lot of controversy in the community. One of the articles that is most highlighted is related to foreign workers, in which the licensing is made easier. For this reason, this regulation needs to be studied from the perspective of maslahah. The purpose of this study is to determine the regulation of foreign workers after the work copyright law and its maslahah perspective. The research method used is normative juridical research with a statute approach and a conceptual approach. The results of this study indicate that Article 42 of the Job Creation Law contains a permit for the use of foreign workers using only RPTKA. In addition, the positions of foreign workers that do not require RPTK $A$ are expanded and added to the positions of directors, commissioners and foreign workers needed in an emergency situation. Furthermore, details of the RPTKA were also deleted. In terms of maslahat, the regulation of foreign workers based on the Job Creation Law is not yet in accordance with the concept of maslahat, because the benefit is only for some people, not for the general benefit.
\end{abstract}

Abstrak: RUU Omnibus Law yang telah disahkan menjadi undang-undang nomor 11 tahun 2020 tentang Penciptaan Pekerjaan banyak menuai kontroversi di masyarakat. Salah satu pasal yang paling disorot adalah terkait tenaga kerja asing, di mana perizinannya dipermudah. Untuk itu, regulasi ini perlu dikaji dari perspektif kemaslahatan. Tujuan dari penelitian ini adalah untuk mengetahui pengaturan tenaga kerja asing menurut undang-undang hak cipta karya dan perspektif maslahahnya. Metode penelitian yang digunakan adalah penelitian yuridis normatif dengan pendekatan undang-undang dan pendekatan konseptual. Hasil penelitian ini menunjukkan bahwa Pasal 42 UU Cipta Kerja memuat izin penggunaan tenaga kerja asing hanya dengan menggunakan RPTKA. Selain itu, jabatan TKA yang tidak memerlukan RPTKA diperluas dan ditambah dengan jabatan direksi, komisaris, dan TKA yang dibutuhkan dalam keadaan darurat. Lebih lanjut, rincian RPTKA juga dihapus. Dari sisi maslahat, pengaturan tenaga kerja asing berdasarkan UU Cipta Kerja belum sesuai dengan konsep masla hat, karena kemaslahatan hanya untuk sebagian orang saja, bukan untuk kemaslahatan umum.

Keywords: Foreign Workers, The Job Creation Act, Maslabah.

\section{INTRODUCTION}

$\mathcal{T}$ he word of Omnibus Law started to be discussed, especially by legal practitioners and government circles after the speech of the Indonesian President
Joko Widodo on October 20, 2019. In his speech, Jokowi said that the government would draft legislation called the Omnibus Law. With the existence of the Omnibus Law, the government invites the DPR to simplify regulations that are felt to 
be convoluted and overlapping so that regulation simplification is carried out by drafting 2 major laws, namely: the Job Creation Act, and the UMKM Empowerment Act. (Pardede, 2020: 171)

At the beginning of 2020, the government began to prepare the Job Creation Act (b.) usually called the draftbill Job Creation Act) using the Omnibus Law concept. The Ciptaker Bill was designed because there is a need to simplify regulations to make it easier for investors to enter to invest in Indonesia. The Ciptaker Bill is considered important due to the high unemployment in Indonesia which reaches 7 million people, so the Ciptaker Bill is expected to be able to open up more jobs to reduce the unemployment rate. (Hanifah, 2021: 159)

The Job Creation Bill was signed by the President of the Republic of Indonesia, Joko Widodo on Monday, October 2, 2020 and became Law no. 11 years old 2020 on Job Creation. The objectives of the establishment of the Employment Creation Law are: 1) Creating and increasing employment opportunities by providing facilities, protection and efforts to empower national industry and trade as an effort to absorb the widest possible workforce. 2) Guaranteeing every citizen to get a job so that he gets fair rewards and treatment in an employment relationship. 3) Adjusting various rules related to the investment ecosystem. (Marbun et al., 2020: 157)

With the enactment of Law no. 11 of 2020 is expected to be able to provide convenience in the field of investment in Indonesia so that it can control economic growth and can create more jobs. (Susanto, 2019: 227)

One of the government's efforts in encouraging investment and accelerating development so as to open up more job opportunities is about making it easier for foreign workers to operate and work in Indonesia. Certain beleid The issue of making it easier for foreign workers to enter Indonesia has raised many concerns from various parties. Previously, the regulation regarding the use of Foreign Workers was regulated in the Manpower Act in articles 42 to 49, while in the Employment Creation Law this rule was changed in article 81 point 4 . (Galih, 2020)

The term Foreign Worker, hereinafter referred to as TKA, is: people who are not Indonesian citizens who work or have a working relationship to produce goods/services (Khakim, 2014, p. 24). Prior to the enactment of Law no. 11 of 2020 concerning Job Creation, the regulation of Foreign Workers is regulated based on Law no. 13 of 2003, namely in articles 42 and 49 which contain licensing procedures, including the Plan for the Use of Foreign Workers (RPTKA), Permit to Employ Foreign Workers (IMTA) (Mahardika \& Sarjana, 2019: 3). Regulations that are more specific and are derivative rules of Law no. 11 of 2020 which regulates the use of Foreign Workers is regulated in the Indonesian Government Regulation No. 34 of 2021 concerning the Plan for the Use of Foreign Workers which was stipulated by the President of the Republic of Indonesia on February 2, 2021 and automatically abolished the Indonesian Government Regulation No.

Every Indonesian citizen has the same rights in obtaining decent work in accordance with the mandate of the UUD 1945 Article 27 paragraph 2 which states that "every citizen has the right to work and a decent living for humanity". Thus, the right of every citizen to obtain a job has been guaranteed by the 1945 Constitution as the basis of the nation's 
life, but in reality there are still many Indonesians who are unemployed.

Based on data from the Central Statistics Agency (BPS), as quoted in kompas.com stated that the number of unemployed workers was around 9.77 million people in August 2020 (Fauzia, 2020), so that with the enactment of Law no. 11 of 2020 concerning Job Creation is one of the government's efforts to reduce unemployment in Indonesia.

Islam not only regulates the relationship between humans and their God, but also regulates the relationship between humans and humans (muamalah) and the relationship between humans and the natural environment. With that, Islam guarantees human happiness in this world and in the hereafter. This guideline consists of morality and law, because the ultimate goal of the sharia economic system is justice and equality. (Anwar, 2018: 85)

The main principle in the formulation of Islamic economic development must lead to the creation of good luck (benefit). One model of the ijtihad approach is maslahah which makes it very vital in the development of Islamic economics and Siyasah Iqtishadiyah (Economic Policy). Based on maslahah, Islamic economics can easily adapt to the development of science and technology. In addition, maslahah is also the essence of sharia policies to respond to economic, social and political dynamics. (Ghafur, 2020: 64-65)

With the enactment of Law no. 11 of 2020 concerning Job Creation, where in the regulation regulates the ease of licensing the use of Foreign Workers, it raises a big question mark, how is the licensing of foreign workers based on the Job Creation Law? Does the regulation regarding the licensing of foreign workers bring benefits or vice versa?

\section{RESEARCH METHODS}

This study uses normative juridical research, namely research that bases its analysis on applicable laws and regulations and is relevant to legal problems that occur (Benuf \& Azhar, 2019: 24). The approach used in this research is a statutory approach and a conceptual approach. The statutory approach is research with an approach that uses laws or norms as the basis for research, while the conceptual approach is a research approach that uses concepts for the problem under study (Ibrahim, 2007: 306). The legal materials used are primary legal materials, namely binding legal materials (Sunggono, 2015: 113) consisting of the 1945 Constitution, Law no. 13 of 2003 concerning Manpower, Law no. 11 of 2020 concerning Job Creation.

\section{RESULTS AND DISCUSSION}

\section{Licensing of Foreign Workers Based on the Copyright Act}

At the beginning of 2020, the Indonesian people and legal practitioners are stirred up by the term omnibus law or ordinary whichcalled the sweep rule of the universe. Omnibus law comes from the Latin word omnis, which is a literary work made by combining several genres/streams at once. Meanwhile, according to Paul as quoted in the book Omnibus Law, that omnibus law is the resolution of various arrangements contained in several laws in one legal umbrella of certain laws (Pardede, 2020: 172). Simply put, an omnibus law is a law that contains several previous laws at once 


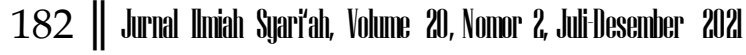

so that there are no overlapping regulations between one law and another.

Use omnibus law in various parts of the world is not a new thing, as was done by the Serbian state in 2002 which regulates the status of the Autonomous Province of Voj Vodina. The same thing was done by the Irish state, even Ireland set a record by streamlining the law which removed around 3.225 articles in one particular law. (Fad, 2020: 35)

In line with use omnibus law in various parts of the world, the Indonesian government has also begun to look at this concept to overcome various overlapping regulations so that they can be applied in Indonesia. In mid-2019, starting from the omnibus law concept, the Job Creation Bill was formed which was finally ratified by the President of the Republic of Indonesia on Monday, October 2, 2020, which became Law Number 11 of 2020 concerning Job Creation.

At the beginning of the formation of the Job Creation Bill, it has caused various polemics in the community. Some responded positively to the bill, but not a few responded with criticism. It is proven that at the time the bill was formed, there were various rejections by means of demonstrationsin various Indonesian territory. (Kartikasari \& Fauzi, 2021: 9)

One of the most highlighted public refusals in the Job Creation Law is regarding employment clusters related to the ease of permits for foreign workers to enter and workin Indonesian territory. Article 1 of the Manpower Law states that foreign workers (TKA) are foreign citizens holding visas with the intention of working in the territory of Indonesia.

The use of foreign workers in Indonesia certainly has a specific purpose, namely to meet the needs of skilled and skilled workers professionalin certain fields that cannot be occupied by local workers, so that the presence of foreign workers is expected to increase investment and encourage Indonesia's economic growth, although state-owned and private companies are still obliged to use local workers as the main workforce. (Yitawati, 2019: 150)

So, what exactly is the regulation regarding foreign workers? postJob Creation Act?. Based on the opinion of the researcher, the following is a comparison of the regulation of foreign workers previously contained in Law no. 13 of 2003 concerning Manpower and Law no. 11 of 2020 concerning Job Creation which is regulated in articles 42 to 49 :

First, Article 42 of the Manpower Law contains procedures for licensing foreign workers that must be owned by employers to employ foreign workers as stated in 6 paragraphs. Article 42 paragraph 1 explains that the employer is required to have a written permit app roved by the relevant minister or official. The permit is regulated in presidential regulation number 20 of 2018 concerning the Plan for the Use of EnergyWork Which foreigner in the rules at least permission consists of a limited stay visa (Vitas), a Plan for the Use of Foreign Workers (RPTKA) and a Permit to Employ Foreign Workers (IMTA). Furthermore, the requirements for employers may not be individuals as contained in paragraph 2. The provisions regarding written permission do not apply to diplomatic and consular employees.

Permit to employ foreign workers (IMTA) is a written permission for the employer of foreign workers given by the relevant official or minister. While the plan for the use of foreign workers (RPTKA) is a document containing plans for the use of foreign workers made by 
employers of foreign workers with a certain period of time signed/approved by the officials/ministers concerned so that the document is one of the requirements for obtaining a permit. employ foreign workers (IMTA). (Z., 2019: 349).

The provisions regarding article 42 of the Manpower Law are amended in the Law no. 11 of 2020. Licensing which originally contained RPTKA and IMTA In the Employment Creation Law, it is narrowed down to only RPTKA, besides that, licensing is no longer through the relevant ministers/ officials, but directly to the central government. The original RPTKA was notapply for diplomatic and consular officers expanded for directors, commissioners and foreign workers needed in an emergency due to production stops, vocational, startup based technology, business visits and research for a certain period of time as contained in Article 42 paragraph (3) letters $\mathrm{a}, \mathrm{b}$ and $\mathrm{c}$.

Second, Article 43 of the Manpower Law contains details of the RPTKA that must be made by employers of foreign workers, at least containing several things such as: (a) reasons for using foreign workers (b) positions given to foreign workers (c) period of time how many the length of use of the foreign workers, and (d) the appointment of Indonesian citizens as assistants for foreign workers. Details regarding RPTKA removedin the Job Creation Law.

Third, Article 44 of the Manpower Law contains about: obligation employers of foreign workers for obey arrangements regarding the positions and work competencies of foreign workers who are madein ministerial decisions. Positions that can be occupied by foreign workers are regulated in the Decree of the Minister of Manpower of the Republic of Indonesia Number 228 of 2019 concerning Certain Positions That Can Be Occupied by Foreign Workers. There are 18 categories of positions that can be occupied by foreign workers, where in each category there are points for the names of any positions that can be occupied by foreign workers. However, Article 44 of the Job Creation Law is abolished.

Fourth, Article 45 paragraph 1 of the Manpower Law requires employers of foreign workers to appoint Indonesian citizens as assistants. In addition, in Article 45 paragraph 1 letter $b$, the employer is obliged toforprovide training and education for foreign workers assistants. The provisions contained in article 45 paragraph 1 do not apply to directors and commissioners. The purpose of holding training and education for assistants is to improve the competence and skills of assistants.

Article 45 of the Job Creation Law has amended the clause. In article 45 paragraph 1, besides containing the obligations of the employer to appoint, carry out education and training for assistant staff, the employer is also obliged to repatriate foreign workers who have finished their work period as stipulated in article 45 paragraph 1 letter c. Provisions regarding the repatriation of foreign workers have previously been regulated in Article 48 of the Manpower Law. Provisionsabout the employer's obligation to appoint assistants and carry out training and education for these assistants, which was originally not applicable to directors and commissioners, was changed to certain positions.

Fifth, Article 46 paragraph 1 of the Manpower Law contains a prohibition on positions occupied by foreign workers, namely personnel positions or certain 
positions. Certain positions referred to inchapter 46 paragraph 1 is further regulated in a ministerial decree. The ministerial decree governing the prohibition of positions occupied by foreign workers is regulated in the Decree of the Minister of Manpower and Transmigration of the Republic of Indonesia No. 40 of 2012 concerning certain positions that are prohibited to be occupied by foreign workers.Position There are at least 19 positions that are prohibited in the candy bar related to the personnel department.

Article 46 in the Job Creation Law has been abolished. Prohibitionrelated The positions occupied by foreign workers in the Job Creation Law are regulated in Article 42 paragraphs 5 and 6.

Sixth, Article 47 of the Manpower Law contains 4 main paragraphs which contain the obligations of employers to foreign workers and the rights obtained by foreign workers. The obligations of employers of foreign workers are contained in paragraphs 1 and 2 which oblige to pay compensation for every foreign worker employed. This obligation does not apply to government agencies, representatives of foreign countries, international agencies, social institutions, religious institutions and certain positions in educational institutions. Certain positions in educational institutions are regulated in a ministerial decree as set out in paragraph 3 . The rights obtained by foreign workers as contained in article 47 paragraph 1 are the amount of compensation received from the employer. The amount of compensation is regulated in a government regulation.

Article 47 in the Job Creation Law has been streamlined, from which previously there were 4 main paragraphs to 3 paragraphs. The changes related to provisions regarding certain positions in educational institutions were abolished. In addition, the provisions regarding the amount of compensation that were originally regulated in a government regulation were amended in the laws and regulations.

Seventh, Article 48 of the Manpower Law contains the obligation of the employer to repatriate foreign workers employed to their country of origin afterthe term of employment or employment contract expires. In the Job Creation Act, this article was abolished because it was already contained in Article 45 letter c concerning the obligation to repatriate foreign workers.

Eighth, Article 49 of the Manpower Law covers at least the regulation regarding the use of foreign workers and the implementation and training of foreign workers accompanying workers as regulated in a presidential decree. In the Job Creation Law, this article is streamlined which contains regulations on the use of foreign workers which are regulated in government regulations, while the clause on implementing regulations and training of foreign workers' assistants is abolished.

\section{Licensing the Use of Foreign Workers Based on the Law on Employment from the Maslahah Perspective}

Maslahah is a form of legal ijtihad in Islam. In his study, maslahah literally means benefit, harmony, goodness, appropriateness and obedience. In terms of maslahah, according to Al-Ghazali, the embodiment of the purpose of law is to maintain religion, soul, mind, lineage and property. Al-Ghazali also emphasized that something that maintains and realizes the purpose of the law is called maslahah, but on the contrary if it destroys the purpose 
of the law it is called mafsadah. (Asmawi, 2014: 314).

Talking about legal purposes cannot be separated from maqashid sharia. Maqashid sharia according to Al-Ghazali is a basic effort to survive, restrain the factors that cause damage and encourage prosperity (Ghafur, 2020: 60). Thus, maqashid sharia is a religious goal by way of outlining Islamic law in order to provide problems to humans by fulfilling the needs of dharuriyah, hajjiyah and tahnisiah.

The main substance of the concept maqashid sharia is maslahah. In terms of influence on human life, according to AsySyatibi, maslahah can be divided into three, namely (Zatadini \& Syamsuri, 2018: 116):

a. Maslahah dharuruiyat (good luck primary) that is good luck the highest position, where humans are very dependent on good luck this, both in terms of religion and the worldly side. If this problem has no life in this world and in the hereafter can be corrupted.

b. Maslahah hajjiyat (good luck secondary) that is maslahah needed by humans to make life easier and eliminate narrowness. If this maslahah does not exist, there will be difficulties and narrowness.

c. Maslahah Tahnisiyat (tertiary maslahah) namely maslahah which is a moral guidance that aims for goodness and glory. If this maslahah does not exist, it will not reach the destructive stage.

Furthermore, Ash-Syatibi is of the opinion that the government for him is the regulator of the people and one of the maslahah dharuriya which must be fulfilled. The form of the government is to fulfill the maslahah for it's people in the world, because the afterlife maslahah cannot be realized if the world's maslahah is not fulfilled. (Zatadini \& Syamsuri, 2018: 241).
If you look at the opinion AshSyatibi about the main function of the government, namely to regulate its people for the sake of achieving benefit. This is in accordance with the rules of fiqh which reads (Djazuli, n.d.,: 147):

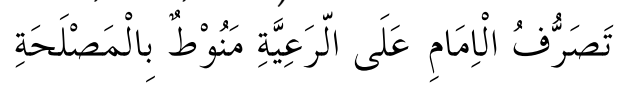

"The policy of a leader to his people depends on the benefit". Thus, a leader taking policies must be seen from the aspect of the benefit, considering that government policies are not only for certain circles, but for the good of all the people.

At the end of 2020, the government signed the Job Creation Law which became Law no. 11 of 2020. In the law, policies regarding foreign workers reap pros and cons among the public. With the latest policies on the employment cluster, of course there is a positive side, but there is also a negative side.

In particular, entrepreneurs responded quite well about the new policy. Because they think that with the new regulation, it will be easier for them to bring in foreign workers to Indonesia who may have more skills and abilities in their field of work. On the other hand, there are still many people who do not have decent jobs due to the limited number of jobs and their lack of competence.

Talking about the workforce, it
cannot be separated from job opportunities and expertise. If it is easier for foreign workers to enter Indonesia, the more foreign workers enter, of course the job opportunities for local workers are getting narrower, where they have to compete with foreign workers who allow more skills and abilities than local workers. 
As the researcher explained above, in article 42 Law no. 11 of 2020 concerning Job Creation, it can be seen that licensing for foreign workers is getting easier. In addition, positions that do not require a permit are also expanded, so of course the job opportunities for local workers are getting narrower. Although, the initial purpose of the enactment of Law no. 11 of 2020 aims to encourage investment so that it can become a path of economic growth.

In the context of controlling foreign workers, the government should consider several aspects, including: (1) the principle of benefit, namely the consideration of whether to encourage the opening of large new employment opportunities for local workers. (2) Aspects of legality and needs. (3) Aspects of human resource development, the point here is whether the entry of foreign workers is able to encourage the quality of human resources for local workers. (Diono, 2016: 39).

Regarding foreign workers, indeed Allah swt has ordered His people to seek sustenance in all corners of the world, this is contained in the letter Al-Jumu'ah verse 10:

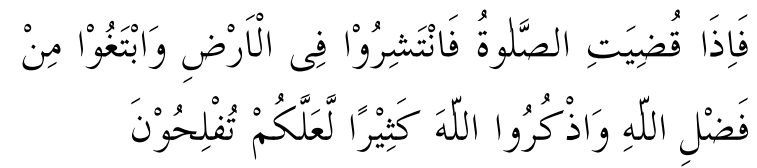

Translation: "When the prayer has been performed, then you are scattered on the earth, and seek the bounty of Allah and remember Allah much so that you may be successful"

The regulation of foreign workers after the Employment Creation Act of course has its maslahah and mafsadah aspects. Judging from the aspect of the problem, the regulationaims to fill vacant positions and positions that are experts and professionals in their fields so that the company can develop its business. From the mafsadat side, if local workers are not able to compete with foreign workers, of course it will have an impact on the increasing unemployment rate.

When viewed from a conditional point of view, good luck can be used as a legal istinbat if it fulfills: (1) Maslahah is a real maslahah not conjecture (2) Maslahah is general not specific (3) Maslahah does not conflict with existing syara' arguments. (Qorib et al., 2016: 67)

Refer to requirements good luckabove, the regulation of foreign workers after the Job Creation Law only brings benefits to a few people, such as companies, certain legal entities and foreign workers themselves. The regulation does not have an impact on the benefit of many people, because local people have to compete for jobs with more and more foreign workers. With the increasing number of foreign workers entering Indonesia, unemployment is also increasing. So that the regulation is more useful for local workers. This applies to the fiqh rule which reads:

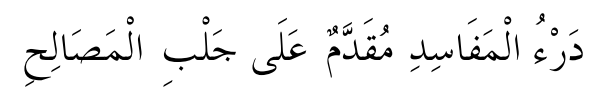

"rejecting evil takes precedence over achieving benefit"

Thus, when viewed from the perspective of good luck, then the regulation of foreign workers is more meaningful for many people. For this reason, it would be better to refuse to reject evil than to benefit only a few people.

\section{CONCLUSION}

Based on the explanation above, it can be concluded that:

Regulations for foreign workers after the Job Creation Law have indeed made it easier for foreign workers to license permits. Article 42 which originally 
required RPTKA and IMTA signed by authorized officials was simplified into RPTKA signed by the central government. In addition, positions that do not require RPTKA which were originally only for diplomatic and consular employees were expanded to positions of directors, commissioners and foreign workers needed in an emergency. Furthermore, the details of the RPTKA which were originally contained in Article 43, in the Job Creation Law were also abolished. The appointment of assistant staff for foreign workers which was originally not valid for directors and commissioners was expanded to be added to certain positions contained in article 49.

When viewed from the point of view good luck, the regulation of foreign workers after the Job Creation Law has not been in accordance with the conception of maslahah, because there are conditions that have not been fulfilled, namely that the general benefit takes precedence over the specific benefit. However, in fact this benefit is only for a few people, especially certain companies and legal entities. while the density is greater, because with the large number of foreign workers entering, the more unemployment in Indonesia. Thus, the regulation of foreign workers after the Job Creation Law is not in accordance with the concept of maslahah.

\section{REFERENCES}

Anwar, S. (2018). Pengantar Falsafah Ekonomi Dan Keuangan Syariah. PT Raja Grafindo Persada.

Asmawi, A. (2014). Konseptualisasi Teori Maslahah. SALAM: Jurnal Sosial Dan Budaya Syar-I, 1(2). https:/ / doi.org/10.15408/sjsbs.v1i2.1 548
Benuf, K., \& Azhar, M. (2019). Metodologi Penelitian Hukum sebagai Instrumen Mengurai Permasalahan Hukum Kontemporer. Metodologi Penelitian Hukum Sebagai Instrumen Mengurai Permasalahan Hukum Kontemporer, 3(2).

Diono, M. (2016). Analisis Terhadap Perubahan Ketentuan Penggunaan Tenaga Kerja Asing Melalui Teori Maslahah Mursalah. JURISDICTIE, $7(1)$.

https:/ / doi.org/10.18860/j.v7i1.3677

Djazuli, A. (n.d.). Kaidah-Kaidah Fikih. Kencana Prenada Media Grup.

Fad, M. F. (2020). Omnibus Law Dalam Tinjauan Hifdzul Mal. El-Mashlahah, 10(1).

https://doi.org/10.23971/maslahah. v10i1.1768

Fauzia, M. (2020). Indonesia Resesi, Jumlah Pengangguran Naik Jadi 9,77 Juta Orang. Kompas.Com. https:/ / www.kompas.com/money/r ead/2020/11/05/141654326/indones ia-resesi-jumlah-pengangguran-naikjadi-977-juta-orang

Galih, B. (2020). UU Cipta Kerja Permudah Tenaga Kerja Asing Bekerja di RI, Ini Perubahannya Artikel ini telah tayang di Kompas.com dengan judul "UU Cipta Kerja Permudah Tenaga Kerja Asing Bekerja di RI, Ini Perubahannya." Kompas.Com. https:/ / nasional.kompas.com/read/ 2020/11/03/08003731/uu-ciptakerja-permudah-tenaga-kerja-asingbekerja-di-ri-iniperubahannya?page $=$ all

Ghafur, A. (2020). Falsafah Ekonomi Syariah. PT Raja Grafindo Persada.

Hanifah, I. (2021). Peluang Tenaga Kerja Asing Untuk Bekerja Di Indonesia Berdasarkan Rancangan UndangUndang Cipta Kerja. Jurnal Ilmu 
Hukm, 6(1), 158. https:// doi.org/10.30596/delegalata. v6i1.5536

Ibrahim, J. (2007). Teori Dan Methodologi Penelitian Hukum Normatif Cetakan Ke-

3. Bayu Media Publishing.

Kartikasari, H., \& Fauzi, A. M. (2021). Penolakan Masyarakat Terhadap Pengesahan Omnibus Law Cipta Kerja dalam Perspektif Sosiologi Hukum. Doktrina: Journal of Law, 4(1), 39-52.

https://doi.org/10.31289/doktrina.v $4 \mathrm{i} 1.4482$

Khakim, A. (2014). Dasar-Dasar Hukum Ketenagakerjaan Di Indonesia. PT Citra Aditya Bakti.

Mahardika, P. G. P., \& Sarjana, I. M. (2019). KAJIAN IZIN PENGGUNAAN TENAGA KERJA ASING DALAM PERATURAN PRESIDEN NOMOR 20 TAHUN 2018. Kertha Semaya: Journal Ilmu Hukum, $7(8)$. https:// doi.org/10.24843/km.2019.v0 7.i08.p15

Marbun, A. T., Wageanto, A., Rusmamto, A. A., \& ... (2020). INVESTASI ASING DAN TENAGA KERJA ASING DI INDONESIA BERDASARKAN UNDANG-UNDANG NOMOR 11 TAHUN 2020 TENTANG CIPTA KERJA. Jurnal Lex http:/ / www.openjournal.unpam.ac.i d/index.php/jlsp/article/view/8579

Pardede, M. (2020). Omnibus Law Dalam Grand Design Sistem Hukum Indonesia (Studi Kasus: UU No.11 Tahun 2020 Tentang CIPTAKER). Papas Sinar Sinanti.

Qorib, A., Harahap, I., Islam, B., \& Su, U. I. N. (2016). Penerapan maslahah mursalah dalam ekonomi islam. Analytica Islamica, Vol. 5 No.(Penerapan Maslahah Mursalah
Dalam Ekonomi Islam), 55-80.

Sunggono, B. (2015). Metodologi Penelitian Hukum. Rajawali Pers.

Susanto, M. I. (2019). Kedudukan Hukum People Power dan Relevansinya dengan Hak Kebebasan Berpendapat di Indonesia. Volksgeist: Jurnal Ilmu Hukum Dan Konstitusi, 2(2), 225-237. https:// doi.org/10.24090/volksgeist. v2i2.2844

Yitawati, K. (2019). Analisis Kebijakan Penggunaan Tenaga Kerja Asing Di Indonesia (Dampak Dikeluarkannya Peraturan Presiden (Perpres) Nomor 20 Tahun 2018 Tentang Penggunaan Tenaga Kerja Asing). YUSTISIA MERDEKA : Jurnal Ilmiah Hukum, 4(2), 148-155.

https://doi.org/10.33319/yume.v4i2. 20

Z., A. V. (2019). Rencana Penggunaan Tenaga Kerja Asing (Rptka) Sebagai Izin Menggunakan Tenaga Kerja Asing di Indonesia. Jurist-Diction, 2(2).

https://doi.org/10.20473/jd.v2i2.142 13

Zatadini, N., \& Syamsuri, S. (2018). Konsep Maqashid Syariah Menurut Al-Syatibi Dan Kontribusinya Dalam Kebijakan Fiskal. AL-FALAH: Journal of Islamic Economics, 3(2), 1. https:// doi.org/10.29240/alfalah.v3i 2.587

Undang-Undang Dasar 1945

Undang-Undang Nomor 13 Tahun 2003 Tentang Ketenagakerjaan

Undang-Undang Nomor 11 Tahun 2020 Tentang Cipta Kerja 